\title{
Caudo-Frontal Depression: A Landmark for Local Anasthesia in the Dehorning of Sahel Goats (Capra hircus)
}

\author{
Shawulu J. C. ${ }^{* 1}$, Omeje J. N. ${ }^{2}$ and Kwari H. D. ${ }^{3}$ \\ ${ }^{1}$ Department of Veterinary Anatomy, University of Abuja, Abuja \\ ${ }^{2}$ Department of Veterinary Medicine \& Surgery, University of Abuja, Abuja \\ ${ }^{3}$ Department of Veterinary Anatomy, University of Maiduguri, Maiduguri
}

\section{Abstract}

The variation in shape and morphology of the head among animals even within the same family is common. Work to determine skull shape have been carried out by some workers. In horned animals, the position of the horns may differ and therefore necessitate the exploration of land marks for local anaesthesia.

The caudofrontal depression of Sahel goats was studied to ascertain its involvement as a possible landmark for the deposition of local anaesthetic substances during dehorning process in this breed. The location of the depression was seen to be along the temporal crest, dorsal to the temporal fossa between the eye orbit and the horns. Data obtained indicates that it has a breadth of $1.01 \pm 0.09 \mathrm{~cm}$ at the left side and of $0.97 \pm 0.14 \mathrm{~cm}$ at the right side in J. Vet. Anat. female animals. Males had $0.84 \pm$ $0.04 \mathrm{~cm}$ at the left and $0.85 \pm 0.13 \mathrm{~cm}$ at the right side with a significant difference $(p=0.0074)$ between them. The mean distance of the depression from the orbital margins were both higher in the female $(1.08 \pm 0.17 \mathrm{~cm}$ for the left and $1.01 \pm 0.16 \mathrm{~cm}$ for the right). Males had mean distance of $1.04 \pm 0.20 \mathrm{~cm}$ and $0.99 \pm 0.20 \mathrm{~cm}$ respectively. It was also discovered to be about half way (range $39.13 \%-45.42 \%$ ) the distance to the horn in the female and (range $21.14 \%-24.12 \%$ ) in the male. The depression was shallow but forms the region of the passage for the cornual nerve branch of the infratrochlear nerve as well as the superficial temporal artery branch supplying the horn. There was no significant difference in its entirety and has no sexual dimorphic features. It was thus concluded to be prescribed as a land-

Vol 6 No 2, (2013) 41 - 49 
mark for direct targeting of the infratrochlear cornual nerves and in the total elimination of blood loss from the superficial temporal artery during dehorning of the Sahel goats.

Keywords: caudofrontal depression, landmark, local anaesthesia, dehorning, Sahel goats.

\section{Introduction}

Sahel goats are predominantly horned ruminants that are widely spread across the sub-Saharan region of Africa (Gall, 1996). In Nigeria, they are found predominantly in the northeastern part of the country (Gall, 1996; Kwari et al., 2004). They are easily identified by some striking features one of which is the curved or twisted horns (Mason and Maule, 1960). The position of the horns at the dorsal profile of the skull is sharply sloping towards the nuchal plane (Sivachelvan et al., 1995). The sizes and lengths of these horns are variable, diverging outwardly (Gall, 1996; Dyce et al., 1996). Horns are known for defense under fright conditions by horned animals. In some species, it is used in ageing processes of adult animals (Aspinall, 1976). In several cases overgrown horns may pose threat to the animal itself, danger to handlers and posses some risk of interference from dominant animals that may bully other animal during feeding or on the farm. This necessitates removal of the horns after they have formed from the horn bud. Physical methods of dehorning (gouge dehorning) include the use of embryotomy wire, guillotine shears, or dehorning knives, saws, spoons, cups, or tubes (AVMA, 2011). Dehorning is also done for cosmetics purposes and most importantly to improve the productiveness of such animals. In most cases dehorning is associated with severe pain and therefore necessitates desensitization. The presence of the cornual diverticulum of the frontal sinus causes surgical dehorning of adult to be more invasive (La Fontaine, 1975; Ward and Rebhun, 1992). A recent finding (Olopade et al., 2006), revealed that the caudofrontal depression exist at the temporal bone equidistant from the zygomatic process of the frontal bone and the base of the horn in Sahel goats. The functional indication of this depression was however not reported in any literature.

The cornual nerve, a branch of the infratrochlear and lacrimal (zygomaticotemporal) nerve, provides sensation to the skin around the base of the horn in goats and sheep (Butler, 1967). The infiltration of a local anesthetic substance around the cornual nerve as it traverses the frontal crest will desensitize the area 
(Hoffis, 1995; Godinho and Getty, 1975). Although in practice, local anaesthesia of goat was possible, many surgeons admitted to the difficulties experienced in achieving it. In most developed Countries, Veterinary surgeons dehorn or disbud goats under general anaesthesia (). However, the use of general anaesthesia on the farm was regarded as impracticable because of the care and attention required during postanaesthesia recovery (Taylor, 1991; Flecknell, 1991). This necessitates the careful and accurate applications of the local anaesthesia. A precise knowledge of the location of reference points in this area provides important data in local anaesthesia.

This study was carried out to ascertain the extent of the depression and its indication as a landmark for cornual nerve block or anesthetic application in the dehorning of Sahel goats.

\section{Material and Methods}

A total of 27 Sahel goat heads were used, measurements were carried out in 17 skulls in this study. The goats were first screened for physical deformities involving the head and aged by the dentition method described by Sissons and Grossman (1975).

\section{Skull processing and cleaning}

The skin and muscles around the skull were gently removed. Tissues around the depression were carefully excised preserving blood vessels and nerves emanating from the temporal fossa. The skulls were thereafter macerated by boiling, a technique described by Onar (1999) and Olopade and Onwuka (2005). Skulls were air dried and the depression studied by physical examination.

\section{Measurements}

Measurement was taken from 17 skulls comprising 7 males and 10 females using a vernier caliper Silverline $^{\circledR}$ with a minimum scale of $0.02 \mathrm{~mm}-0.001$ ".

The indices measured are;

1. Distance from the neck of the horn to the margin of the depression (T)

2. The breadth of caudofrontal depression (CD)

3. The distance from the depression to the margin of the orbital circumference (OD)

The data obtained were analysed with a Graph pad Instat ${ }^{\circledR}$ prism, a soft ware for statistical analysis of raw data from the Gaussian distributions using the method of Kolmogorov and Smirnov. The result was presented as mean $\pm S D$ values.

\section{(n)}

Vol 6 No 2, (2013) 41 - 49 


\section{Results}

The result (Table 1) shows that females had higher bilateral depression breadth of $1.01 \pm 0.09 \mathrm{~cm}$ at the left side and of $0.97 \pm 0.14 \mathrm{~cm}$ at the right side. Males had $0.84 \pm 0.04 \mathrm{~cm}$ at the left and $0.85 \pm 0.13 \mathrm{~cm}$ at the right side with a significant difference $(p=0.0074)$ between them. The distance of the depression to the orbital margins were both higher in the female $(1.08 \pm 0.17 \mathrm{~cm}$ for the left and $1.01 \pm 0.16 \mathrm{~cm}$ for the right). Males had $1.04 \pm 0.20 \mathrm{~cm}$ and $0.99 \pm 0.20 \mathrm{~cm}$ respectively. The distance between the depression and the neck of the horns were $0.53 \pm 0.10 \mathrm{~cm}$ and $0.56 \pm 0.15 \mathrm{~cm}$ in the female, while male had $0.49 \pm 0.12 \mathrm{~cm}$ and $0.59 \pm 0.10 \mathrm{~cm}$ respectively which are insignificantly lower than those of the females. The location of the depression from the eye orbit is about half the entire length to the horns obtained both in males and females (range 39.13\% $45.42 \%$ ) (Table2). The distance to the neck of the horns was less obtained from the percentile mean distance (range $21.14 \%$ - 24.12\%). The depression lies along the temporal crest, dorsal to the temporal fossa. Because of its oval outline (fig 1) it limits the parietofrontal suture. It is shallow and forms passages for cornual nerve branch of the infratrochlear nerve and the branch of the superficial temporal artery to the horn (fig 2). The cornual nerve branch of the infratrochlear nerve runs backward from the eye orbit to the horn (fig. 3). The differences observed between the male and the female does not show any significant differences to depict sexual dimorphism.

\section{Discussion}

The shape and the appearance of the head are very important in determining the character of an animal (Dyce et. al., 1996) and in the dehorning process of horned animals (Buttle et. al., 1986). The gross morphology of this region shows clearly blood supply through the temporal arterial branch of the zygomatotemporal artery and nerve innervations to the tissues around the horns (Sissons and Grossman, 1975). The findings also concur with the report that nerve supply to the horn region in the goat and sheep is via the cornual branches of the lachrymal (zygomaticotemporal) and infratrochlear nerves (Butler, 1967). Both of these nerves must be blocked prior to dehorning. It also concur with the report of Bourne, (2011), Vitums (1954) that infratrochlear nerve block is achieved at the dorso-medial margin of the orbit and that it can be done half way the distance between the eye 
and the horn (Jenkins, 1986); the nerve may be palpable as it emerges under the skin to innervate the horn. It is however less so in polled animals (Sissons and Grossman, 1975).

The involvement of the depression was never reported in any available literature as well as the cornual nerve and vessels emanating from the temporal fossa to the horns. A comparison with museum specimens of horned animals however revealed the absence of this depression in the cattle, antelope but appears far less distinct in the sheep. However, Olopade et al., (2006) observed the existence of this depression in the three major breed (Sahel, Maradi and West African dwarf goats) of goats in Nigeria. All these breeds of goats spread across the sub- Saharan Africa as reported by Gall, (1996). Dehorning of goats on farm is not practicable under general anaesthesia (FAWC, 1980). Hence, local anaesthesia application is carried out by targeting the cornual nerves and then after anaesthetizing them. The corneal nerve branch of the infratrochlear nerve runs backward from the eye orbit as reported by Edwards (2001) in cattle. Morphological land marks have been used in physical examination and are necessary in clinical applications of anaesthesia in surgical operations such as dehorning
(Machen et. al., 2008; Buttle et. al., 1986). Dehorning should be performed under a local anesthetic and the animal monitored for hemorrhage and infection (AACG, 1988). This is to reduce the post-surgical care a dehorn animal might require on the farm. Several different methods can be used to dehorn animals (Ensminger, 1980; Etgen, et al., 1987). These include chemical treatments, such as calcium chloride injections and caustic sticks; cutting instruments such as dehorning tubes, gouge dehorners, saws, and Barnes dehorners; and also electrical dehorners. Dehorning by these methods is accomplished by eliminating the blood supply to the horn tissue. If the blood supply is not totally eliminated, partial or complete horn re-growth can occur. This work is believed to aid the dehorning process of Sahel goats by prescribing landmark for direct targeting of the infratrochlear cornual nerves and in the total elimination of blood loss during dehorning of the Sahel goats.

\section{References}
Agricultural Animal Care Guide (1988): Guide for the Care and Use of Agricultural Animals in Agricultur- al Research and Teaching, ASAS/ADSA Association Headquar- ters, Champaign, IL. 
American Veterinary Medical Association's Animal Welfare Division (2011): Welfare Implications of the Dehorning and Disbudding of Cattle. J Amer Vet Med Assoc, Accepted June, 82011.

Aspinall, K. W. (1976): First steps in Veterinary Sciences. ELBS and Bailliere Tindall. Pp 18-21.

Bourne, D. (2011): Cornual block in Goats and Sheep: local anaesthetic techniques. British Veterinary Association London, UK, ISSN 00424900. Retrieved from http:// wildpro. twycrosszoo.org/S/00Ref/JournalCo ntents/j03.htm

Butler, W. F. (1967): Innervation of the horn region in domestic ruminants. British Veterinary Association, London, UK vol. 80: 490-492, ISSN 0042-4900.

Buttle, B., Mowlem, A. and Mews, A. (1986): Disbudding and Dehorning of Goats. British Veterinary Association London UK vol. 8:63 -65, ISSN 0263-841X.

Dyce, K. M; Sack, W. O \& Wensing, C. J. G. (1996): Textbook of Veterinary Anatomy, $2^{\text {nd }}$ ed. Philadelphia, Saunders.
Edwards B. (2001): Regional anaesthesia techniques in cattle. In: Pract. 23: 142-149

Ensminger, M. E. (1980): Dairy Cattle Science $2^{\text {nd }}$ Edition, The Interstate Printers and Publishers, Inc., Danville, IL.

Etgen, W. M., James, R. E. and Reaves, P. M. (1987): Dairy Cattle Feeding and Management, John Wiley and Sons, Inc., New York, NY.

Farm Animal Welfare Council (1980): Report on the Animal Welfare Implications of the Harvesting of Deer antlers in velvet. Retrieved from http:// harvesting-deer-antlersin-velvet-report-feb1980.pdf.

Flecknell, P. (1991): Anaesthesia and post-operative care of small mammals. British Veterinary Association London UK, vol. 13: 180189, ISSN 0263-841 X.

Gall, C. (1996): Goat breeds of the world. $1^{\text {st }}$ ed. Margraf., verlag, weikershem, Germany.

Godinho, H. P. and Getty, R. (1975): Bovine cranial nerves. In: Sisson and Grossman's the anatomy of the domestic animals. 
Hoffsis, G. (1995): Surgical (cosmetic) dehorning in cattle. Vet Clin. Food Anim., 11:159-169.

Jenkins, W.L. (1986): Disposition of anesthetic and anesthetic-related agents in ruminants $2 \mathrm{~s}: 527-552$

Kwari, H. D., Sivachelvan, M. N. and Chibuzo, G. A. (2004): Characterization of Sahel goats in Borno state, Nigeria for certain qualitative traits, Nig. J. of Exp. and Appl. Biology, vol. 5:2, pp. $151-154$.

La Fontaine, D. (1975): Dehorning and castration of calves under six months of age, 5th ed. Philadelphia: WB Saunders Co., 1084-1085. Accessed March 24, 2006.

Machen, R., Holland, E. and Thigpen, W. (2008): Agricultural Research Services United States Department of Agriculture. Ret. from http//: www.goatworld.com.

Mason I. L. and Maule, J. P. (1960): The indigenous livestock of eastern and Southern Africa. Technical Communication No. 14. Commonwealth Bureau of Animal breeding and Genetics, Commonwealth Agricultural Bureaux: Farnham Royal.

Olopade, J. O.; Onwuka, S. K.; Kwari, H. D. and Oke, B. O. (2006): Discovery of a depression on the cornual end of the temporal line of the skull of goats breeds in Nigeria. Int. J. Morphol., 24(3):349350.

Olopade, J. O. and Onwuka, S.K. (2005): Some Aspects of the Clinical Anatomy of the Mandibular and Maxillofacial Regions of the West African Dwarf Goat in Nigeria. Int. J. Morphol., 23(1):33-6.

Onar, V. (1999): A morphometric study of the skull of the German shepherd dog (Alsatian). Anat. Histol. Embryol., 28, 253-6.

Sissons, S and Grossman, J. D. (1975): The Anatomy of the Domestic Animals, vol. 2, $5^{\text {th }}$ ed. W. B. Saunders Company, Philadelphia.

Sivachelvan, M. N., Hajara, B. U. and Chibuzo, G. A. (1995): Fetal Development of the Calvarium in Sahel Goats: Its post-natal significance. Tropical Veterinarian, 13, 109-188.

Taylor, P.M. (1991): Anaesthesia in sheep and goats. British Veterinary Association London UK, vol. 13:3136, ISSN 0263-841 X.

Vitums, A. (1954): Nerve and arterial supply to the horns of the goat with reference to the sites of anesthesia for dehorning.J Am Vet Med Assoc 125:284-286. 
Caudo-frontal depression in Sahel goats Shawulu et al.

Ward, J. L. and Rebhun, W. C. J Amer Vet Med Assoc; 201:326(1992): Chronic frontal sinusitis in 328. dairy cattle: 12 cases (1978-1989).

\section{*Corresponding author:}

Email: james.shawulu@ymail.com

Tel. +2347063345777, +2348026586738

Table (1): Mean \pm SD width of the depression, distance to the base of the horn and from orbital margin

\begin{tabular}{|c|c|c|c|c|c|c|}
\hline Parameters & \multicolumn{2}{|c|}{$\begin{array}{l}\text { Breadth of depression } \\
(\mathrm{CD})(\mathrm{cm})\end{array}$} & \multicolumn{2}{|c|}{$\begin{array}{l}\text { Distance to the orbital } \\
\text { margin }(O D)(\mathrm{cm})\end{array}$} & \multicolumn{2}{|c|}{$\begin{array}{l}\text { Distance to the neck } \\
\text { of the horn }(T)(\mathrm{cm})\end{array}$} \\
\hline $\begin{array}{l}\text { Male } \\
n=7\end{array}$ & $0.84 \pm 0.04$ & $0.85 \pm 0.13^{*}$ & $1.04 \pm 0.20$ & $0.99 \pm 0.20$ & $0.49 \pm 0.12$ & $0.59 \pm 0.10$ \\
\hline $\begin{array}{l}\text { Female } \\
n=10\end{array}$ & $1.01 \pm 0.09$ & $0.97 \pm 0.14$ & $1.08 \pm 0.17$ & $1.01 \pm 0.16$ & $0.53 \pm 0.10$ & $0.56 \pm 0.15$ \\
\hline
\end{tabular}

Table (2): Mean percentile values of parameters

\begin{tabular}{|c|c|c|c|c|c|c|}
\hline \multirow[t]{2}{*}{$\begin{array}{l}\text { Parame- } \\
\text { ters }\end{array}$} & \multicolumn{2}{|c|}{$\begin{array}{l}\text { Breadth of depression } \\
\text { (CD) }(\%)\end{array}$} & \multicolumn{2}{|c|}{$\begin{array}{l}\text { Distance to the orbital } \\
\text { margin (OD) }(\%)\end{array}$} & \multicolumn{2}{|c|}{$\begin{array}{l}\text { Distance to the neck } \\
\text { Of the horn }(T)(\%)\end{array}$} \\
\hline & $\mathrm{L}$ & $\mathrm{R}$ & $\mathrm{L}$ & $\mathrm{R}$ & $\mathrm{L}$ & $\mathrm{R}$ \\
\hline $\begin{array}{l}\text { Male } \\
n=7\end{array}$ & $32.23(\%)$ & $34.27(\%)$ & $45.42(\%)$ & $41.61(\%)$ & $22.34(\%)$ & $24.12(\%)$ \\
\hline $\begin{array}{l}\text { Female } \\
n=10\end{array}$ & $36.91(\%)$ & $37.12(\%)$ & $41.95(\%)$ & $39.13(\%)$ & $21.14(\%)$ & $23.75(\%)$ \\
\hline
\end{tabular}




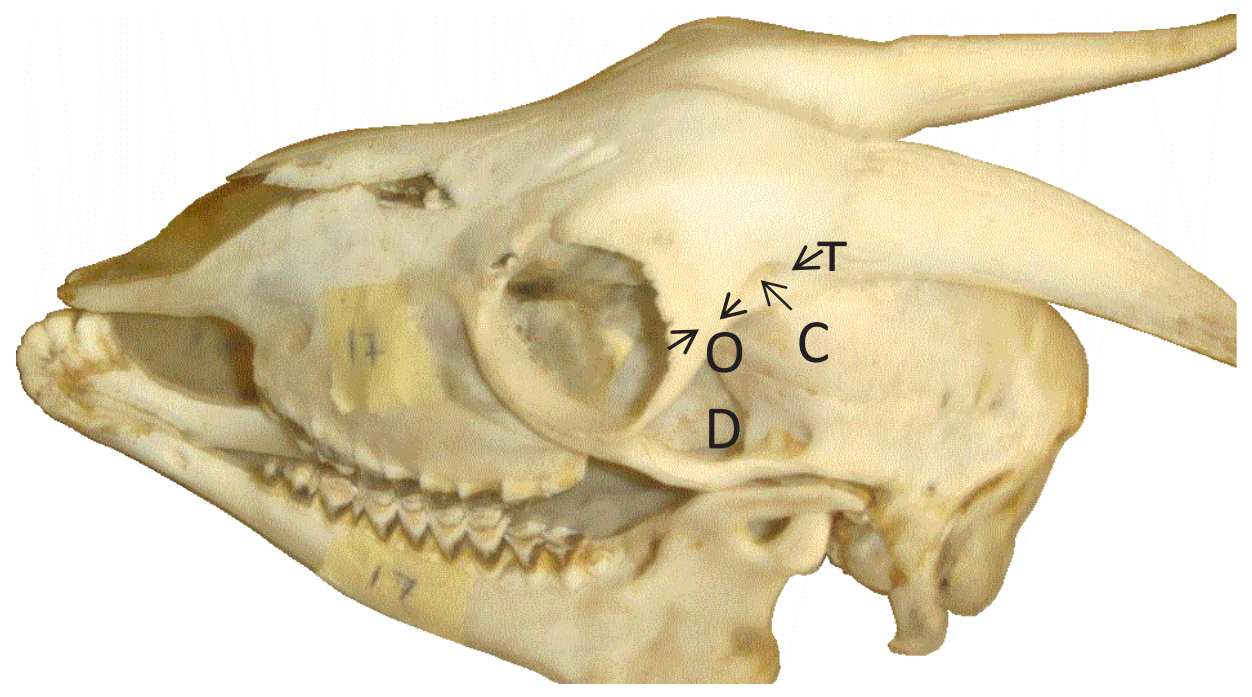

Fig (1): The skull of the Sahel goat showing the caudofrontal depression (Cd), distance from the eye orbit (OD) and the distance to the neck of the horn (T).

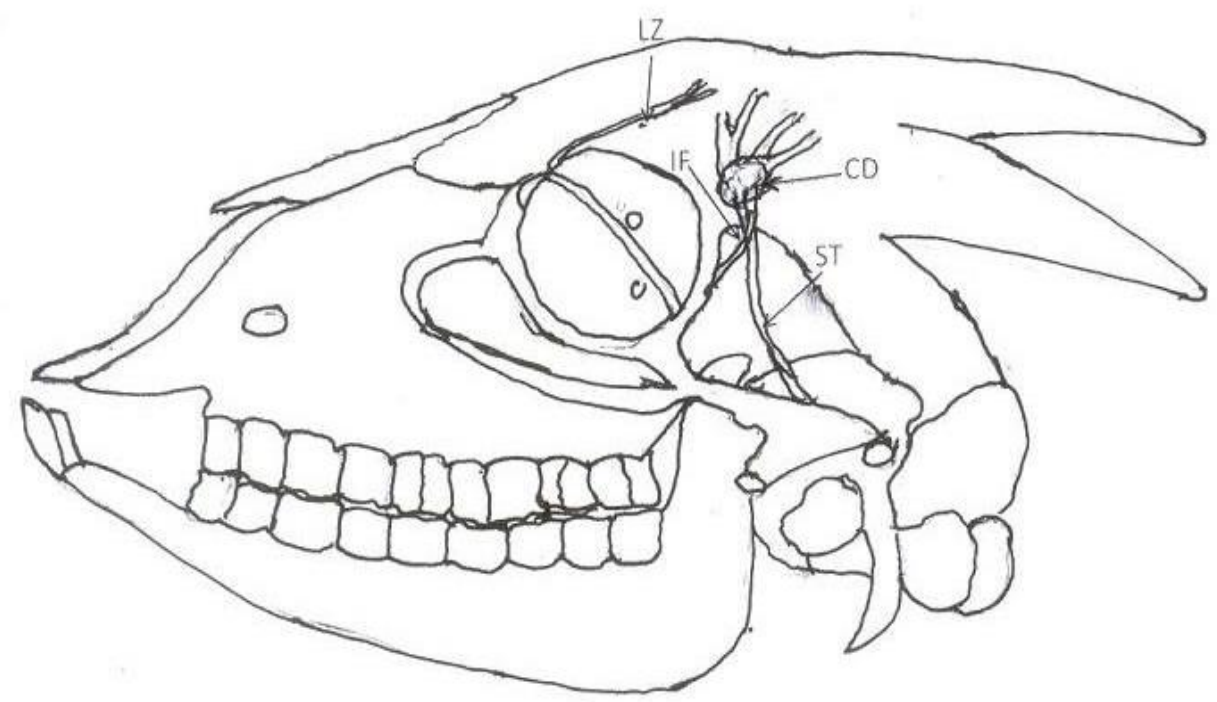

Fig (2): Schematic diagram of the Sahel goat skull depicting the nerve and blood supplies to the horns (LZ) lacrimozygomatic nerve (IF) infratrochlear nerve, (ST) superficial temporal artery and (CD) caudofrontal depression. 